\title{
SUFISME DALAM DINAMIKA KEHIDUPAN MASYARAKAT MUSLIM KONTEMPORER
}

\author{
Nur Kafid \\ UIN Surakarta, Indonesia \\ Email: mashafid@gmail.com
}

\begin{abstract}
This paper aims to discuss on Sufism and social change, especially regarding to its existence and role in the contemporary lives of Muslim societies. Based on the literature study, wherein the data is collected from various works related to Sufism critically, the results of the study show that Sufism has very complex developments in the dynamics of contemporary Muslim society. Beside to its definition, practice, existence and role in community life, the background of Sufism followers is even more diverse. In addition, there are Sufism figures/leaders who were actively involved in various social and political movements, and even Sufism bas become a structured community and has a major role in social change.
\end{abstract}

Keywords: Sufism; socio-political dynamics; and social change.

Abstrak. Paper ini bertujuan untuk membahas tentang sufisme dan perubahan sosial, terutama mengenai eksistensi dan perannya dalam kehidupan masyarakat Muslim kontemporer. Dari hasil studi pustaka, di mana data diperoleh dari penelusuran dan bacaan kritis atas berbagai karya terkait sufisme, hasil studi menunjukkan bahwa sufisme telah mengalami perkembangan yang sangat kompleks dalam dinamika kehidupan masyarakat Muslim kontemporer. Selain definisi, praktik, eksistensi dan perannya dalam kehidupan masyakarat, latar belakang pengikut sufisme pun makin beragam. Selain itu, tidak sedikit pula para tokoh sufisme yang terlibat aktif dalam berbagai gerakan sosial dan politik. Bahkan sufisme telah menjadi komunitas yang terstruktur dan memiliki peran besar dalam perubahan sosial kemasyarakatan.

Keywords: Sufisme; dinamika sosial-politik; dan perubahan sosial.

Permalink/DOI: https://doi.org/10.15408/mimbar.v37i1.18232 


\section{Pendahuluan}

Sufisme, dari sejak kemunculannya sampai dengan hari ini, masih dan akan tetap menjadi fenomena dan diskursus yang menarik perhatian para ahli di bidang sosial-keagamaan. Terutama terkait dengan eksistensi dan perannya di dalam kehidupan masyarakat Muslim kontemporer.

Sufisme, dalam sejarah perjalanannya bukanlah sesuatu yang bersifat statis. Sufisme terus mengalami perkembangan seiring dengan dinamika perubahan kehidupan masyarakat. Mulai dari definisi atau makna sufisme, praktik dan aliran-aliran yang berkembang di dalam sufisme, model keanggotaan sufisme, hingga perannya dalam kehidupan sosial masyarakat Muslim pun terus mengalami perkembangan yang kompleks dan dinamis.

Jika dilihat dari sisi definisi, terutama pada masa awal kemunculannya, sufisme lebih dipahami sebagai "mistisisme Islam" atau "esoterisme Islam". (Hill, 2019). Jika dilihat dari sisi linguistik, dalam istilah Arab, kata yang seringkali dirujuk untuk memahami sufisme adalah kata "tasawmuf," yang berarti upaya pengejaran penanaman spiritual yang dilakukan oleh seseorang; atau "suatu proses menjadi sufi"; atau aktifitas 'menjauh' atau 'menarik diri' dari urusan dunia dengan tujuan untuk lebih mendekatkan diri kepada Tuhan. Sehingga sufisme diasosiasikan sebagai orang atau sekelompok orang saleh (ashab as shuffa) yang bertemu dan tinggal di masjid Madinah dalam rangka untuk mempelajari pengetahuan esoteris dengan Nabi Muhammad SAW. (Cook, 2014).

Jika merujuk pada definisi tersebut, tentu tidak salah jika sufisme dipahami sebagai sebuah bentuk praktik dan model keberagamaan yang pasif dan jauh dari peran sosial kemasyarakatan. Sebab sufisme diandaikan sebagai sikap dan tindakan yang menjaga jarak, atau bahkan menjauhkan diri dari realitas duniawi. Jika mengacu pada definisi ini, maka tidak heran jika para cendekiawan dan pemikir modernis menganggap sufisme sebagai bentuk dan praktik tradisi kuno, sehingga diprediksikan tidak akan dapat berkembang. Ajarannya dianggap tidak lagi relevan dengan kehidupan masyarakat modern yang rasional. (Bruinessen, 2019). Bahkan pada akhir Abad ke- 18 Masehi, ketika gerakan reformasi muncul dalam dunia Islam, muncul pula berbagai sikap ambivalen terhadap praktik sufisme. (Bruinessen, 2019). Beberapa kelompok gerakan yang secara keras menolak sufisme, karena menganggap praktik dan ajarannya kental dengan unsur pemujaan, bid'ah dan tahayyul, antara lain seperti kelompok Wahabi, kelompok Ahli Hadits India dan kelompok Salafi puritan. Bahkan dalam konteks tertentu, sufisme dianggap sebagai bentuk penyimpangan dari ajaran Islam murni. Clifford Geertz (Geertz, 1971) dan Ernest Gellner (Gellner, 1981), pernah memberikan catatan bahwa bentuk Islam reformis yang lebih puritan akan menggantikan tradisionalisme Islam mistis. Hal yang hampir sama juga diprediksikan terjadi di Mesir (Hoffman, 2009).

Prediksi tersebut, ternyata bertolak belakang dengan realitas sejarah sufisme di era modern. Sufisme justru mengalami perkembangan luar biasa, bahkan menjadi lebih kompleks di masa kontemporer. Sufisme tumbuh dan berkembang melampaui wilayah asal kemunculannya, Jazirah Arab. Sufisme kini telah menyebar luas ke hampir seluruh belahan dunia. Para pengikutnya pun berasal dari beragam latar belakang kelas sosial. (Cook, 2014). Ketika sufisme pada mulanya digambarkan sebagai praktik keberagamaan yang cenderung pasif, apolitis, dan jauh dari proses perubahan sosial, realitas sejarah justru menunjukkan bahwa tidak sedikit dari para tokoh dan pengikut sufisme yang justru turut berperan aktif dalam proses politik dan perubahan sosial. 
Selain itu, makna sufisme pun mengalami perkembangan yang lebih luas. Sufisme dimaknai sebagai setiap orang yang berpartisipasi dalam praktik hidup sufi, terutama setelah adanya inisiasi formal dari seorang guru (mursyid), meskipun orang tersebut tidak menjauhkan diri dari kehidupan sehari-hari (kehidupan duniawi) (Hazen, 2011).

Memang tidak ada definisi tunggal mengenai sufisme yang disepakati oleh para ahli, tetapi setidaknya istilah "sufi" secara umum dipahami sebagai bentuk "pengakuan" pengetahuan intuitif, pewahyuan dan pengalaman seseorang tentang Tuhan dan dunia; adanya bentuk penerimaan dari masyarakat atau komunitas Muslim; adanya janji bahwa mereka yang telah mencapai pengetahuan semacam itu dapat menularkannya kepada pengikutnya, seringkali melalui teknik meditasi; penggambaran proses transformasi diri sebagai jalan menuju Tuhan yang melibatkan pencapaian maqomat; keyakinan bahwa proses tersebut harus dilakukan dengan komunitas; keyakinan bahwa transformasi diri membutuhkan bantuan pemandu (guru) spiritual (mursyid) yang memiliki silsilah tidak terputus sampai pada Nabi Muhammad SAW; adanya kewajiban timbal-balik antara guru spiritual dan pengikut; meyakini bahwa guru spiritual adalah waliyyullah; dan tidak boleh meninggalkan praktik bacaan harian (zikir), baik yang sifatnya individual maupun kelompok.

Jika merujuk pada definisi tersebut, sufisme bukanlah sesuatu yang sederhana dan monolitik. (Cook, 2014). Sufisme merupakan kumpulan tradisi yang kaya, beragam, dinamis dan kompleks. Sufisme telah berkembang secara global, dengan variasi latar belakang pengikut. Baik dari sisi sosialbudaya, ekonomi, pendidikan maupun etnis. Meski di beberapa negara Muslim, seperti Turki (terutama pada masa kepemimpinan kelompok modernis- reformis) (Faiz, 2017) dan Arab Saudi (yang cenderung Islamis) (Sedgwick, 1997) negara sangat membatasi bahkan melarang perkembangan sufisme (komunitas sufi/tarekat), tetapi pada praktiknya tetap banyak orang yang bergabung dan mempraktikkan tradisi sufi.

\section{Konseptualisasi Sufisme Di Era Kontemporer}

Perkembangan sufisme yang kian kompleks dan dinamis di era kontemporer, setidaknya dibutuhkan tiga (3) pendekatan baru untuk dapat memahaminya (J. D. Howell, 2007); pertama, melibatkan fokus pada hubungan antara organisasi agama 'tradisional' dan orang dari agama 'populer' kontemporer; kedua, fokus pada hubungan antara globalisasi dan pengembangan struktur sufisme (tarekat); dan ketiga, sufisme (tarekat) ditempatkan dalam kerangka konseptualisasi agama di era 'postmodern'.

Dalam konteks 'kebangkitan agama' secara global, menempatkan organisasi sufisme (tarekat), terutama dalam posisinya sebagai bentuk struktural kehidupan keagamaan 'populer' dunia Muslim, baik di wilayah perkotaan maupun pedesaan menjadi hal yang sangat penting. Jika teori "lama" melihat perkembangan sufisme (tarekat) dengan menggunakan basis teori sekularisasi atau modernisasi (Kafid, 2014), dan/atau pemahaman orientalis tentang 'Islam populer', maka di masa kontemporer ini diperlukan perangkat teoritis baru untuk memahami perkembangan sufisme sebagai sebuah gerakan sosial baru (new social movement). Para ahli gerakan sosial, memeriksa berbagai jenis format organisasi 
sebagai "struktur mobilisasi yang digunakan suatu kelompok untuk berorganisasi" dan memeriksa "kendaraan kolektif itu, baik formal maupun non-formal, di mana orang memobilisasi dan terlibat dalam aksi kolektif'.(J. D. Howell, 2007). Mengingat, terdapat perbedaan tajam-yang tentu tidak dapat diabaikan—terkait tatanan budaya elite dan budaya massa (kehidupan relijius masyarakat). Ditambah lagi dengan adanya ketegangan antara puritanisme ilmiah urban dan praktik Islam populer yang terkait dengan sufisme (kelompok tarekat).

Dalam konteks globalisasi dan pembangunan kontemporer, Ronald Inglehart (Inglehart, 1997), menyimpulkan bahwa tren "ketika orang-orang biasa mendapatkan sumber daya yang lebih besar beralih dari petani yang buta huruf menjadi orang yang relatif aman dan berpendidikan, maka keseimbangan antara elit dan massa mengalami pergeseran ke arah massa”. Selain itu, perkembangan teknologi informasi dan komunikasi yang cepat pun turut merubah kemampuan 'orang biasa' menjadi mampu berkomunikasi dan berpartisipasi dalam suatu kegiatan di luar wilayah terdekat mereka sebelumnya. Seseorang dapat menangkap perubahan dengan melihat perubahan sifat kehidupan 'orang biasa', dan 'budaya populer tradisional' telah berubah menjadi 'budaya pop'. Orang yang 'bukan ulama' — atau setidaknya tidak lahir dari tradisi keilmuan sebagaimana ditempuh oleh para ulama—dapat memainkan peran penting dalam mendefinisikan dimensi relijius dalam kehidupan sehari-hari. (White, 2012).

Karena sufisme (tarekat) sudah menjadi bagian penting dari struktur Islam populer, posisinya di dalam masyarakat pun telah berubah. Beberapa bentuk sufisme (tarekat) telah melakukan transisi, dengan sufisme sebagai dimensi 'budaya pop' dalam beragam konteks sosial. Struktur organisasi sufisme (tarekat dari model tradisional) pun telah mengalami banyak inovasi menjadi organisasi yang lebih efektif di dalam kehidupan masyarakat kontemporer. Transisi dari menjadi bagian utama budaya Islam populer 'tradisional' ke posisi memainkan sentral (memainkan peran penting) dalam budaya massa masyarakat Muslim dalam upaya mencerminkan kekuatan berkelanjutan dari tradisi sufisme (tarekat) di era kontemporer. Sufisme, yang dulunya hanya terkait dengan sektor pedesaan (tradisional), dalam perkembangannya telah mengilhami antusiasme baru, bahkan di sektor masyarakat yang paling intens terlibat dalam modernisasi dan globalisasi: kelas menengah dan atas di wilayah perkotaan. Minat ini diekspresikan melalui partisipasi kaum urban dalam tarekat sufi berbasis pedesaan yang telah lama didirikan, tetapi melalui bentuk kelembagaan baru di kota-kota besar dan kecil.

Di samping itu, struktur organisasi gerakan sosial tidak hanya muncul dalam ruang hampa, tetapi dalam pola interaksi yang sudah ada di antara individu dan kelompok. (Doug McAdam, John D. McCarthy, 1996). Proses sosial yang sudah tertanam dapat mengubah pola sosial yang membentuk rangkaian mobilisasi bentuk struktural yang tersedia di setiap titik waktu, tetapi mereka dapat menemukan yang baru dan mengubahnya secara kreatif untuk mencapai tujuan kolektif. Di dalam konteks inilah, struktur sufisme (tarekat) menjadi bagian dari berbagai alternatif yang tersedia dan digunakan sebagai format organisasi untuk mengekspresikan Islam populer baru, karena berinteraksi dengan dimensi kehidupan sosial, ekonomi dan politik yang melingkupinya.

Pada sisi lain, sufisme (tarekat) yang seringkali dianggap sebagai inti dari budaya dan masyarakat Muslim setempat; dalam konteks globalisasi, agama justru dipandang sebagai bagian penting dari pembaruan partikularis dan menjadi 'sumber daya penting' untuk gerakan aktivis partikularisme. Bahkan, gerakan keagamaan 'sering menampilkan opsi 'konservatif dengan tekanan khasnya pada 
kekuatan relativisasi globalisasi sebagai manifestasi utama kejahatan di dunia'. (Beyer, 1994). Selain itu, perspektif globalisasi juga menyediakan perlunya memahami kombinasi 'lokalisme' dan 'transnasionalisme' untuk tren sufisme global, seperti Jamaah Tabligh; termasuk untuk memahami tren model baru 'spiritualitas sufi' di kalangan Muslim urban di Indonesia. (J. D. Howell, 2007). Di sinilah, konsep 'glokalisasi' menjadi bagian penting dari "mode kebangkitan" Islam dan tasawuf kosmopolitan.

Sufisme (tarekat) kontemporer juga sering dilihat dalam kerangka kerja konseptual sebagai 'postmodern'. Di mana peran agama sangat berbeda dari peran yang ditetapkan dalam 'modernitas'. Institusi dan perspektif keagamaan pun berubah. Kerangka kerja teori gerakan sosial dapat dijadikan sebagai alternatif perspektif. Fenomena 'sufi baru' telah memberikan contoh signifikan tentang gaya khas tasawuf yang muncul pada awal abad ke-21. 'Sufi baru' ini mencerminkan dinamika masyarakat yang di satu sisi memiliki kesinambungan dengan masa lalu, tetapi juga memiliki perbedaan format dari yang berkembang pada masyarakat kolonial modern dan sistem politik di banyak bagian dunia Muslim setelah kemerdekaan. Para sufi baru pasca-kolonial mengilustrasikan cara baru, dengan model pemasaran relijius wirausaha dan konsep-konsep sintesis keagamaan yang berbeda.

Para ahli melihat, bahwa sifat utama dari gerakan sosial telah berubah secara signifikan dalam 50 tahun terakhir, dan perubahan itu membantu untuk menentukan sifat dari apa yang dapat dianggap sebagai gerakan 'post- modern'. Gerakan sosial baru yang mulai muncul pada tahun 1960 melibatkan isu-isu yang berbeda dari yang memobilisasi orang- orang di masyarakat industri modern sebelumnya. Isu-isu lama yang mendefinisikan sifat gerakan sosial dengan melibatkan konflik atas distribusi barang (material), konflik baru tidak hanya dipicu oleh masalah distribusi, tetapi juga menyangkut tata bahasa bentuk kehidupan. Artikulasi 'tata bahasa' ini merupakan proyek keagamaan dan transisi dari 'modern' ke 'post-modern' merupakan dimensi penting dalam 'kebangkitan agama' pada akhir abad ke-20.

Meskipun dimensi relijius dari kemunculan postmodern sangat signifikan, tetapi model lama dari operasi keagamaan tidak harus dipulihkan. Dengan menggunakan analisis tentang kemunculan postmaterialisme, setidaknya beberapa kelompok sufisme (tarekat) lebih dapat dipahami sebagai manifestasi postmodernisme dan postmaterialisme. Model post-materialisme sufisme dapat dilihat pada 'sufisme zaman baru' yang mulai menarik banyak pengikut di Amerika Serikat dan Eropa Barat pada 1960an.Julianne Hazen, "Contemporary Islamic Sufism in America: The Philosophy and Practice of the Alami Tariqa in Waterport, New York." Gerakan tersebut memiliki akar penting dalam gerakan 'sufi internasional', meskipun ada banyak tren khas dalam sufisme Barat. Bagi banyak profesional kelas menengah perkotaan dan mereka yang mencari gaya hidup alternatif, bagian utama dari daya tarik sufisme Barat adalah penyediaan sumber daya untuk pelarian spiritualis dari masyarakat materialis.

Di sinilah kerangka analisis Inglehart (Hazen, 2011), yang menempatkan gerakan sosial baru dalam konteks historis era postmodern dan postmaterialis, menawarkan kemungkinan menyediakan konteks global yang lebih luas untuk perbandingan. Tarekat postmodern berbeda, tetapi mereka juga dapat dilihat sebagai bagian dari pola adaptasi global yang lebih luas terhadap kondisi di mana agenda modernitas tidak lagi dominan. Hipotesis postmaterialis menawarkan cara untuk bergerak melampaui kerangka lama yang mengidentifikasi tarekat sebagai bagian dari 'pra-modern' yang berinteraksi dengan modernitas. Selain itu, sufisme (tasawuf) telah menunjukkan kemampuan untuk beradaptasi dengan persyaratan yang diperlukan dari gerakan keagamaan dan sosial dalam masyarakat kontemporer. 
John O. Voll (Voll, 2007), menawarkan tiga pendekatan untuk memahami sufisme kontemporer; pertama, kerangka kerja mapan yang menganggap sufisme (tasawuf) sebagai Islam "tradisional" atau "populer" di daerah pedesaan, sebagai lawan dari Islam "modern" di wilayah perkotaan, harus direstrukturisasi untuk mengakuinya sebagai sarana ekspresi (keberagamaan) yang penting. Untuk tren agama baru di antara populasi massal di lingkungan pedesaan dan perkotaan. Kedua, karena dikotomi Islam "lokal" dan "global" tidak lagi relevan, maka dampak lokal maupun global pada gerakan sufi harus dieksplorasi. Ketiga, melampaui dikotomi Islam "modern" dan "tradisional", karena beberapa ekspresi sufisme (tasawuf) kontemporer juga mencerminkan masyarakat postmodern. Ini termasuk "New Age Sufism”, yang berkembang dari aspek masyarakat kontemporer.

Namun tren sufisme kontemporer dalam kasus tertentu, seperti sufisme urban, bukan berarti tidak dapat dianalisis menggunakan perspektif lama. (Rubaidi, 2018). Sebagai contoh kasus, Majelis Shalawat Muhammad sebagai representasi urban sufisme, menunjukkan bahwa teori cultural broker (Geertz) dan cultural transetter (Hirokosi) tetap diperlukan untuk mengungkap kontribusi besar sufisme dalam perubahan sosial masyarakat terhadap nilai maupun ideologi dari luar. Sistem nilai yang inheren dalam sufisme yang disimbolisasi melalui mursyid, (selain sebagai cultural broker, juga sekaligus sebagai cultural transetter) dalam menyikapi nilai dan ideologi dari luar, telah menjadi sistem tradisi dan budaya baru.

\section{Sufisme Dalam Dinamika Perubahan Sosial}

Sejak Abad ke-12 Masehi, praktik sufi paling banyak dijumpai dalam bentuk tarekat. Setiap tarekat didirikan oleh satu atau lebih tokoh yang dianggap memiliki silsilah tidak terputus sampai kepada Nabi Muhammad SAW. Sebagian besar tidak memiliki organisasi tunggal, dibagi menjadi beberapa sub-garis keturunan, dan masing-masing terdiri dari satu atau lebih guru (mursyid) dan murid. Untuk dapat menjadi bagian (anggota) dari komunitas tarekat ini, diperlukan semacam transmisi ritual (zikir) oleh seorang mursyid yang diperoleh melalui proses baiat. (Cook, 2014).

Umumnya, para pendiri tarekat adalah para cendekiawan Muslim yang ahli dalam bidang Alquran, Hadist, Fikih dan beberapa disiplin ilmu lainnya. Mereka meyakini bahwa praktik tasawuf (sufi) membutuhkan pemahaman yang kuat atas disiplin ilmu-ilmu lain yang bersumber pada dari teks-teks Islam klasik. Meskipun tradisi sufi masih memiliki ruang untuk pertapa (khalwat), sebagian besar praktisi sufi modern dan kontemporer menggabungkan pengolahan spiritual dengan keluarga dan kewajiban terkait pekerjaan (hal- hal yang bersifat duniawi). Model ini diyakini sebagai bentuk yang saling melengkapi antara dimensi hidup lahiriyah dan batiniyah. Model dan praktik sufisme seperti inilah yang dalam perkembangan selanjutnya, menjadikan sufisme lebih mudah diterima oleh masyarakat modern di berbagai belahan dunia.

Pada awal Abad ke-20 Masehi, sejumlah tokoh telah memperkenalkan pemikiran, praktik dan budaya sufi ke masyarakat di belahan dunia, termasuk di negara-negara Barat dan Eropa. Mereka menghadirkan sufisme sebagai bentuk kearifan Timur.Julianne Hazen, "Contemporary Islamic Sufism in America: The Philosophy and Practice of the Alami Tariqa in Waterport, New York." Praktik 
sufisme dihadirkan sebagai bentuk kemudahan dalam memeluk Islam, karena mudah beradaptasi (tidak konfrontatif) dengan budaya lokal. (Azra, 1999). Maka tidak heran jika beberapa di antara tokoh sufi, ada kemudian yang mendirikan pondok sufi di Afrika, Asia Tengah, Asia Tenggara, Spanyol, Balkan, Mesir, dan Irak, Amerika, dan beberapa bagian dari negara- negara di kawasan Eropa.

Seiring dengan perkembangan dan persebaran sufisme, terjadi pula tren peningkatan jumlah kelompok tarekat dan varian latar belakang anggotanya. Jika keanggotaan sufisme sebelumnya lebih banyak didominasi oleh kalangan orang tua, mayoritas berasal dari wilayah pedesaan, dan umumnya berpendidikan 'rendah', perkembangan di masa modern dan kontemporer justru menunjukkan tingginya keterlibatan kaum muda perkotaan, berpendidikan tinggi dan berpikiran modernis yang tertarik dengan model keberagamaan ala tasawuf. Tren ini juga terjadi terjadi di Indonesia dan negaranegara di kawasan Asia Tenggara pada umumnya. (J. D. Howell, 2007).

Bahkan pada tahun 1970-an, tarekat seolah menemukan legitimisasi baru sebagai kebutuhan untuk merespon gelombang kolonialisme. (Bruinessen, 2019). Sehingga dalam waktu yang cukup singkat, pengikut tarekat berhasil meningkat pesat di berbagai wilayah kepulauan di Indonesia. Tarekat Qadiryyah wa Naqsabandiyah (TQN) misalnya - tanpa bermaksud mengesampingkan kelompok tarekat yang lain-tercatat memiliki peran besar dalam pemberontakan kepada pemerintah kolonial di wilayah Banten pada tahun 1888. Bahkan hingga kini, TQN tercatat sebagai kelompok tarekat dengan jaringan dan anggota terbesar di Indonesia. (Rosyid, 2018).

Selain itu, pada era ini pula di berbagai belahan dunia yang lain, sufisme (tasawuf) juga telah menjadi sesuatu yang menarik antusiasme laki-laki maupun perempuan di daerah perkotaan maupun pedesaan. Sufisme (tasawuf) telah berhasil membentuk kelembagaan baru sebagai jembatan ekspresi tradisional Islam dengan skripturalisme modern melalui berbagai bentuk adaptasi, di antaranya melalui musik, puisi, dan melalui tarian perdamaian universal (Rumi). (Hazen, 2011).

Pada perkembangan berikutnya, muncul istilah "neo-sufisme" yang menggambarkan perubahan dalam sufisme (akhir 1800-an dan awal 1900-an), yang ditandai dengan munculnya kepatuhan kuat terhadap sharia dan sunah, penolakan terhadap praktik bid'ah, ekstatik, dan adanya kecenderungan jihadis. Meskipun istilah ini juga merujuk pada ekspresi kontemporer sufisme (tasawuf) yang muncul sebagai bentuk kritik berlebihan dari dalam dan mempromosikan kepatuhan terhadap sharia. (J.D. Howell, 2007). Kelompok ini berbeda dengan sufisme klasik, terutama dalam hal pelacakan silsilah spiritual para pendahulunya. Kelompok ini tidak mementingkan adanya kesinambungan silsilah, tetapi mengklaim memiliki hubungan spiritual langsung dengan Nabi Muhammad SAW, dan kebanyakan kelompok ini cenderung diikuti oleh kelompok Salafi. Gerakan yang sering disebut sebagai gerakan pembaharuan sufisme (tasawuf), juga terjadi di Indonesia. (Al- Kumayi, 2013).

Selain telah berhasil berperan besar dalam menyebarluaskan ajaran Islam ke berbagai belahan dunia, sufisme melalui pengaruh para tokohnya juga telah menjadi penggerak sosial dan politik yang unik dan efektif. Para pengkaji tasawuf melihat bahwa latihan spiritual kelompok sufi sangat terikat dengan cita-cita perubahan sosial dan politik. Para penguasa seringkali melihat para pemimpin sufi sebagai musuh atau sekutu potensial paling kuat. (Faiz, 2017). 
Di Indonesia, pada masa pemerintahan Orde Baru, periode yang dianggap bahwa Islam ortodoks telah menggantikan model relijiusitas sinkretistik (Bruinessen, 2017), ketika pemerintah melakukan berbagai upaya untuk melemahkan gerakan Islam politik dan lebih mendukung penyebaran kesalehan pribadi Muslim, muncullah kelas menengah Muslim perkotaan yang relatif makmur dan sadar diri sebagai Muslim. Daya tarik eklektik dengan dunia roh dan teknik memanfaatkannya dalam mengejar kekuatan supernatural telah menjadi bagian dari habitus elit. Pada masa inilah sufisme yang berorientasi sharia mengalami peningkatan popularitas, baik di wilayah pedesaan maupun perkotaan. Sehingga muncul struktur informal tarekat sufi dan asosiasi yang lebih formal di tingkat nasional.

Pemikiran sufi, terutama mengenai dunia sebagai emanasi Tuhan dan paralelisme mikrokosmos dan makrokosmos, dengan mudah diasimilasi dengan sistem klasifikasi dan kontrol magis dunia yang sudah ada sebelumnya. Berbagai latihan sufi, baik dalam bentuk qikir atau wirid, teknik pernapasan, metode meditasi dan kontemplasi, ditambah dengan teknik memperoleh kekuatan spiritual menjadikan tarekat lebih mudah beradaptasi dengan tradisi dan budaya lokal yang berdampak pada gerakan mistik dan magis asli Indonesia. (Ummah, 2018). Bahkan pada ada akhir Abad ke-19 dan paruh pertama Abad ke- 20 Masehi, meski belum masif, telah muncul afiliasi sufi/tarekat internasional. Jaringan ini memiliki stabilitas lebih besar dari waktu ke waktu dibandingkan dengan kebanyakan guru lokal. Pada periode inilah terjadi peningkatan jumlah pesantren dan variasi madrasah di Jawa. Para kiai yang kebanyakan juga berafiliasi kelompok sufi besar, memiliki jaringan kontak di berbagai tempat dan negara dengan anggota dari beragam kelas sosial.(Mashar, 2016). Sehingga tidak mengherankan jika banyak dari para kiai tersebut (secara langsung mupun tidak langsung) juga terlibat aktif dalam berbagai kegiatan sosial dan politik.

Meskipun di dalam sufisme (tarekat) terdapat doktrin tentang zubud- mengosongkan keinginan untuk sesuatu, atau membatasi keinginan untuk mendapatkan sesuatu yang bersifat duniawi-namun peran yang dilakukan beberapa pemimpin tarekat di era modern dan kontemporer dapat menjadi contoh nyata, bagaimana keterlibatan sufisme dalam proses perubahan sosial dan politik. (Ziadi, 2018).

Tarekat Hirib Nabdlatul Wathan di Lombok, Nusa Tenggara Barat misalnya, sang pendiri yang juga sekaligus sebagai guru mursyid-nya terlibat aktif dalam gerakan politik di Lombok. Di Mesir, Hasan al-Banna (1906- 1949)—sebagai mursyid 'am tarekat Shadhiliyya Hashafiyya dari organisasi Ikhwanul Muslimin yang berasal dari organisasi sufi-juga mengambil langkah gerakan untuk melakukan perubahan, meski kemudian mengalami kegagalan dalam upaya menjembatani kesenjangan sufi-salafi yang lebih keras dan dominan dalam menyuarakan gerakan salafi dibanding sufisme. Di Suriah, beberapa syekh dari tarekat Naqshbandi tetap menjadi anggota sentral Ikhwanul Muslimin, dengan menganjurkan jalan tengah dalam menentang rezim sekuler Suriah, dan menghindari ekstremisme keras dan ekses sufi.

\section{Praktik Sufisme Kontemporer}

Seiring dengan perkembangan arus teknologi informasi dan komunikasi, jaringan sufime pun turut mengalami perkembangan. Peran sosial, model organisasi dan penyebarannya pun mengalami perubahan. Internet menjadi salah satu media yang digunakan dalam penyebaran ajaran dan praktik tarekat Naqshbandi Haqqani, di Amerika Serikat. Pengikut tarekat ini adalah campuran imigran dari 
berbagai negara Muslim, di mana sebagian besarnya adalah kaum berpendidikan, berkulit putih, dan mualaf kelas menengah. (Hazen, 2011). Tarekat ini memiliki puluhan situs web, meskipun pada level kelompok lokal, mereka tetap terhubung secara vertikal dengan syekh melalui kunjungan langsung. Tarekat ini memiliki salah satu fungsi sosial, sebagai ruang dan tempat bagi para imigran dari berbagai latar belakang untuk menjadi sebuah lingkungan kepercayaan, perlindungan spiritual, keluarga pengganti dan koneksi dengan negara asal.

Kemampuan kelompok sufi melakukan perubahan sosial, juga menjadi daya tarik tersendiri bagi masyarakat Muslim kontemporer. Gerakan Gulen (Sulaiman, 2016) misalnya, telah berhasil melakukan inovasi sufisme agar ajarannya mampu merespon perubahan yang terjadi dalam kehidupan manusia modern. Kelompok ini melakukan reinterpretasi dan kontekstualisasi ajarannya, seperti konsep-konsep kunci tasawuf-zuhud, inbisat, dan hizmet_secara kreatif ke komunitas internal dan eksternal dengan aksi nyata gerakan sosial dan kemanusiaan.

Di Indonesia, fenomena sufisme kaum urban juga menunjukkan tren perkembangan yang luar biasa. Keberadaan kelompok 'Majelis Dzikir and Shalawat Nurul Mustafa', dapat menjadi contohnya. (Zamhari, 2013). Kelompok ini menunjukkan bahwa tasawuf telah tumbuh secara signifikan di dalam komunitas muslim perkotaan yang terdidik, bahkan sebagian anggotanya berasal dari kelompok elit nasional di Indonesia.

Dari sinilah terlihat, bahwa sufisme telah mengalami pembaruan signifikan dalam konteks praktik, metode dan organisasinya. Dari yang sebelumnya terkesan eksklusif (tidak populer) karena kebanyakan didominasi oleh orang tua dari wilayah pedesaan, cenderung kurang terdidik, kini dengan berbagai berbagai metode penyampaian substansi yang kreatif dan didukung dengan berbagai peralatan modern dalam berbagai aktifitasnya, telah mampu menarik minat kaum muda untuk hadir dan bergabung dalam berbagai ritual yang dilakukan. Organisasi sufi (tasawuf) yang sebelumnya hanya dapat dipraktikkan melalui sejumlah kelompok sufi terorganisir (tarekat), kini justru tidak menuntut harus tergabung dengan struktur untuk dapat mempraktikkan ritualnya.

Namun demikian, meningkatnya tren sufisme urban ini tidak lantas menjadikan akar klasiknya pudar. Akar sufisme klasik justru makin menguat, seperti yang direpresentasikan oleh Majelis Shalawat Muhammad di wilayah Surabaya dan Bojonegoro. (Rubaidi, 2018). Sufisme model ini memiliki kontribusi besar dalam perubahan sosial masyarakat. Sistem nilai yang inheren di dalamnya, yang disimbolisasi melalui mursyid, tidak hanya sekedar berperan sebagai cultural broker, tetapi juga cultural transetter dalam pembentukan pikiran dan perilaku pengikutnya.

\section{Penutup}

Sufisme bukanlah satu konsep dengan definisi yang tunggal. Bentuk ekspresi, organisasi dan gerakannya sangat beragam dan dipengaruhi oleh setting sosial-budaya dan situasi politik di mana sufisme lahir dan berkembang. Meski pada awal perkembangannya, sufisme dianggap sebagai praktik keagamaan kuno, mengandung unsur bid'ah, tahayul, dan jauh rasionalitas masyarakat modern sehingga diprediksikan akan punah, di era modern dan kontemporer justru mengalami perkembangan luar biasa. 
Sufisme mengalami perkembangan pesat, tidak hanya di tempat awal kemunculannya-Jazirah Arabtetapi juga di wilayah Asia, Afrika, Amerika dan Eropa.

Derasnya arus urbanisasi, globalisasi, pertumbuhan ekonomi dan perubahan sosial- politik ternyata tidak mengarah pada upaya marginalisasi sufisme. Sebaliknya, justru meningkatkan posisi dan peran sufisme dalam tatanan sosial-politik dan budaya masyarakat Muslim kontemporer. Sufisme yang pada awalnya digambarkan sebagai model keberagamaan yang pasif, cenderung apolitis dan jauh dari proses perubahan sosial, realitasnya justru sangat kompleks. Tidak sedikit para pengikut sufi yang justru berperan aktif dalam aktifitas politik dan gerakan sosial. 


\section{DAFTAR PUSTAKA}

Al-Kumayi, S. (2013). Gerakan Pembaruan Tasawuf di Indonesia. Jurnal THEOLOGIA, 24(2), 247278. https://doi.org/10.21580/TEO.2013.24.2.335

Azra, A. (1999). Renaisans Islam Asia Tenggara: Sejarah Wacana dan Kekuasaan. Bandung: Remaja Rosdakarya.

Beyer, P. (1994). Religion and Globalization. London: Sage Publications Ltd.

Bruinessen, M. van. (2017). Saints, Politicans and Sufi Bureucrats: Mysticism and Politics in Indonesia's New Order. In Sufism and the Modern in Islam (pp. 92- 335). New York: I.B.Tauris \& Co Ltd.

Bruinessen, M. Van. (2019). Sufism, "Popular" Islam and the Counter with Modernity. In Islam and Modernity: Key Issues and Debates (pp. 125-157). Edinburgh: Edinburgh University Press,.

Cook, B. G. (2014). Understanding Sufism: Contextualising the Content. University of Tasmania.

Doug McAdam, John D. McCarthy, M. N. Z. (1996). Comparative Perspective on Social Movement: Political Opportunities, Mobilizing Structurem and Cultural Framings (M. N. Z. Doug McAdam, John D. McCarthy, Ed.). Cambridge: Cambridge University Press.

Faiz, M. (2017). Risalah Nur dan Gerakan Tarekat di Turki: Peran Said Nursi pada Awal Pemerintahan Republik. Al-A'raf : Jurnal Pemikiran Islam Dan Filsafat, 14(1), 23-46. https://doi.org/10.22515/ajpif.v14i1.588 Geertz, C. (1971). islam Observed: Religious Development in Marocco and Indonesia. Chicago: University of Chicago Press.

Gellner, E. (1981). Muslim Society. Cambridge: Saint Joseph’s University.

Hazen, J. (2011). Contemporary Islamic Sufism in America: the Philosophy and Practice of the Alami Tariqa in Waterport, New York. School of Oriental and African Studies University of London.

Hill, J. (2019). Sufism between Past and Modernity. In R. L.-B. Mark Woodward (Ed.), Handbook of Contemporary Islam and MuslimLives (pp. 1-26). https://doi.org/10.1007/978-3319-73653-2_9-1

Hoffman, V. J. (2009). Sufism, Mystics, and Saints in Modern Egypt. Columbia: University of South Carolina Press.

Howell, J. D. (2007). Sufism and the "Modern" in islam. In edited by M. V. B. and J. D. Howell (Ed.), I.B.Tauris \& Co Ltd. https://doi.org/10.15408/sdi.v10i3.628

Inglehart, R. (1997). Modernization and Postmodernization: Cultural, Economic, and Political Change in 43 Societies. Princeton: Princeton University Press.

Kafid, N. (2014). From Personal to Social Transformation: A Phenomenological Study on the Life of “Kyai Kampung.” JurnalKomunitas, 6(2)， 189-196. https://doi.org/10.15294/komunitas.v6i 1.3313

Mashar, A. (2016). Genealogi dan Penyebaran Thariqah Qadiriyah wa Naqshabandiyah di Jawa. AlA'raf : Jurnal Pemikiran Islam Dan Filsafat, 13(2), 233-262. https://doi.org/10.22515/ajpif.v13i2.75 
Rosyid, M. (2018). Potret Organisasi Tarekat Indonesia dan Dinamikanya. Religia; Jurnal Ilmu-Ilmu Keislaman, 21(1), 78-95. Rubaidi, R. (2018). The Role of Urban Sufism of Shalawat Muhammad Assembly on Urban Middle Class Society. Jurnal Ushuluddin, 26(2), 183. https://doi.org/10.24014/jush.v26i2.489 5

Sedgwick, M. (1997). Saudi Sufis: Compromise in the Hijaz, 1925-40. Die Welt Des Islams, 37(3), 349-368. https://doi.org/10.1163/157006097259 7039

Sulaiman, S. (2016). Perubahan Sosial Berbasis Tasawuf: Studi Kasus Fethullah Gülen Dan Gülen Movement. Al-Tahrir: Jurnal Pemikiran Islam, 16(1), 21-46. https://doi.org/10.21154/al- tahrir.v16i1.359

Ummah, E. O. S. So. (2018). Tarekar, Kesalehan Ritual, $\quad$ Spiritual $\quad$ dan $\quad$ Sosial: Praktik Pengalaman TarekatSyadziliyah di Banten. Al-A'raf : Jurnal Pemikiran Islam Dan Filsafat, 15(2), 315-334. https://doi.org/10.22456/2527- 2616.94434

Voll, J. O. (2007). Asian Islam in the 21st Century (O. B. John L. Esposito, John O. Voll, Ed.). Oxford: Oxford University Press.

White, G. F. dan S. (2012). Ustadz Seleb: Bisnis Moral dan Fatwa Online: Ragam Ekspresi Islam Indonesia Kontemporer (I). Depok: Komunitas Bambu.

Zamhari, A. (2013). Socio-Structural Innovations in Indonesia's Urban Sufism: the Case Study of the Majelis Dzikir and Shalawat Nurul Mustafa. Journal of Indonesian Islam, 7(1), 119_ 144. https://doi.org/10.15642/JIIS.2013.7.1.1 19-144

Ziadi, M. R. (2018). Tarekat dan Politik: Studi Living Sufism Tarekat Hizib Nahdlatul Wathan. Living Islam: Journal of Islamic Discourses, 1(2), 231. https://doi.org/10.14421/lijid.v1i2.1613 